\title{
CHEMICAL COMPOSITION, ANTIMICROBIAL AND ANTIOXIDANT ACTIVITY OF PHYTOLACCA AMERICANA L. FRUITS AND LEAVES EXTRACTS
}

\author{
IOANA CRISTINA MARINAȘ ${ }^{1,2}$, ELIZA OPREA $^{3 *}$, ELISABETA-IRINA GEANĂ ${ }^{4}$, CRISTINA \\ MIHAELA LUNTRARU ${ }^{5}$, CERASELA ELENA GIRDD ${ }^{6}$, MARIANA-CARMEN CHIFIRIUC $^{1,7}$ \\ ${ }^{1}$ Research Institute of the University of Bucharest-ICUB, 91-95 Splaiul Independenței, Bucharest, Romania University of \\ Bucharest and Faculty of Biology, Microbiology Department, 1-3 Portocalilor Way, 060101, Bucharest, Romania \\ ${ }^{2}$ National Institute of Research and Development for Food Bioresources - IBA Bucharest, 6 Dinu Vintilă Street, 021102, \\ Bucharest, Romania \\ ${ }^{3}$ University of Bucharest, Faculty of Chemistry, Department of Organic Chemistry, Biochemistry and Catalysis, 4-12 Regina \\ Elisabeta Boulevard, 030018 Bucharest, Romania \\ ${ }^{4}$ National Research and Development Institute for Cryogenics and Isotopic Technologies - ICIT Rm. Vâlcea, 4 Uzinei Street, \\ PO Râureni, 240050 Râmnicu Vâlcea, Romania \\ ${ }^{5}$ S.C. Hofigal Export Import S.A., Research Development Patents Department, no. 2 Intrarea Serelor Street, district 4, \\ Bucharest, Romania \\ 6“Carol Davila” University of Medicine and Pharmacy, Faculty of Pharmacy, 6 Traian Vuia Street, 020956, Bucharest, \\ Romania \\ ${ }^{7}$ Academy of Romanian Scientists, Bucharest, Romania
}

*corresponding author: eliza.oprea@g.unibuc.ro

Manuscript received: November 2020

\begin{abstract}
The study aimed to investigate the chemical composition, antimicrobial and antioxidant activity of alcoholic extracts obtained from Phytolacca americana leaves and berries. The total phenols, flavonoids (spectrophotometric method, HPLC), carotenoids, betalains, saponins, antioxidant activity (ABTS and DPPH methods) and antimicrobial activity of $P$. americana were assayed. The highest content of phenols $(323.80 \mu \mathrm{g} / \mathrm{mL}$ extract), flavonoids $(9.27 \mu \mathrm{g} / \mathrm{mL}$ extract) and saponins $(1.61 \mathrm{mg} / \mathrm{mL}$ extract) was obtained for $P$. americana leaves extract. The HPLC analysis performed in this study fills an important knowledge gap regarding the profile of Phytolacca phenolic compounds. The P. americana extracts exhibited a selective antimicrobial effect against Gram positive and Gram negative bacterial strains and yeasts (Candida sp). Minimum inhibitory concentrations ranged from $25-200 \mu \mathrm{L} / \mathrm{mL}$, the fruits extracts proving to be the most active, probably due to higher amount of betacyannins $(76.11 \%$ from the total betalains content).
\end{abstract}

\section{Rezumat}

Studiul a avut ca scop investigarea compoziției chimice, precum și a activității antimicrobiene și antioxidante a extractelor alcoolice obținute din frunze și fructe de Phytolacca americana. Au fost determinate concentrațiile de fenoli totali, flavonoide (metoda spectrofotometrică şi HPLC), betalaine, carotenoide, saponine, şi activitatea antioxidantă (ABTS şi DPPH) şi anti-microbiană. Cele mai mari concentraţii de fenoli, $(323,80 \mu \mathrm{g} / \mathrm{mL}$ extract), flavonoide $(9,27 \mu \mathrm{g} / \mathrm{mL}$ extract $)$ şi saponine $(1,61 \mathrm{mg} / \mathrm{mL}$ extract) au fost obținute în cazul extractului de frunze de $P$. americana. Analiza HPLC efectuată în acest studiu completează lipsa de date referitoare la profilul compuşilor fenolici ai speciei $P$. americana. Extractele de $P$. americana au prezentat un efect antimicrobian selectiv împotriva tulpinilor bacteriene Gram pozitive şi Gram negative şi levurice (Candida sp). Concentrațiile minime inhibitorii au variat între 25 și $200 \mu \mathrm{L} / \mathrm{mL}$, extractul din fructe dovedindu-se a fi mai activ, probabil datorită conținutului mai mare de betacianine $(76,11 \%$ din total de betalaine).

Keywords: Phytolacca americana L., antioxidant activity, antimicrobial activity, phenols

\section{Introduction}

Phytolacca americana L. (pokeweed) is a perennial herb, native from eastern North and South America which has been used in traditional medicine in its native area for antimicrobial, anti-inflammatory, anti-cancer and stimulator effects [20].

The leaves' triterpenoid saponins with irritant and anti-inflammatory activities, flavonoids, a high percentage of $\mathrm{C}$ and $\mathrm{B}$ complex vitamins, and a pokeweed-derived $\mathrm{N}$-glycosidase ribosomalinactivating protein with anti-viral activity have been described [10]. Phytolacca extracts, containing esculentosides, display a range of pharmacological activities, including antibacterial, anti-viral, antifungal, anticancer and antiparasitic activities [2].

The phenols from pokeweed were scarcely investigated, despite their potential health-promoting 
properties, mainly as antioxidants, antiinflammatory, anticancer and antimicrobial agents [8]. The increased antibiotic resistance in the recent years has led to the development of new strategies to fight microbial pathogenesis and development. Therefore, intensive research is needed to evaluate the antimicrobial potential of phenols alone or in mixtures with saponins of the $P$. americana fruits and leaves extracts. On the other side, toxic effects, such as vomiting and abdominal pain [5] have been observed after accidental [5] or repeated administration of pokeweed plant roots [11].

The aim of the study consists of the determination of chemical composition, antimicrobial and antioxidant activities of $P$. americana leaves and fruits extracts.

\section{Materials and Methods}

Plant material. Plants were harvested at physiological maturity period (July - September 2018), from the Botanical Garden "Dimitrie Brandza", Bucharest, Romania. The working plant materials were represented by $P$. americana leaves and fruits. The plants were manually sorted and dried at room temperature. The species was identified by the Department of Botany from the Faculty of Biology, University of Bucharest, Romania. A voucher specimen was deposited in the herbarium of the Botanical Garden "Dimitrie Brandza" from the University of Bucharest (No. 400712). The loss on drying for plant raw material was $62.33 \%$ and $72.73 \%$, and the content of extractives soluble in extractant (ethanol $70 \%$ ) were $27.14 \%$ and $28.76 \%$ (on a dry basis) for fruits and leaves, respectively. Plant extracts. The extraction was performed by using an ultrasonic bath (Elma Sonic $80 \mathrm{H}$ ), with frequencies ranging from $20 \mathrm{kHz}$ to $2000 \mathrm{kHz}$, which increases the permeability of cell walls and causes cell lysis, thereby making possible the extraction of biologically active compounds. 2.2880 $\mathrm{g}$ of dried leaves were extracted with $30 \mathrm{~mL} 70 \%$ ethanol [17]. The extract resulted was filtered while the residual was extracted three times and brought to $100 \mathrm{~mL}$ with the same solvent over the first extract. The procedure was repeated for fruits when a quantity of $1.1310 \mathrm{~g}$ was used. The extracts were stored in tightly closed containers at $4{ }^{\circ} \mathrm{C}$. The dry residue (in $70 \%$ ethanol) was $0.36 \%$ and $0.76 \%$ for fruits and leaves, respectively.

Determination of total phenols (TPC). The total phenols content (TPC) was assessed out by FolinCiocâlteu method [21]. The calibration curve with standard solutions of gallic acid concentrations ranging from 5 to $150 \mathrm{mg} / \mathrm{L}$ was traced. The TPC was expressed as $\mathrm{mg}$ of gallic acid equivalents (GAE)/mL extract.
Determination of total flavonoids (TFC). It was applied the aluminium chloride method [24]. The total flavonoids content was expressed in $\mathrm{mg}$ quercetin/g of product and was calculated using the calibration curve obtained for concentrations of quercetin in the range of $0-120 \mathrm{mg} / \mathrm{mL}$.

Determination of total carotenoids. The method was based on xanthophyll ester saponification developed by Ciulei and Istudor [6]. The total carotenoid content from leaves and berries extracts was determined at wavelength of $465 \mathrm{~nm}$, using $\beta$ carotene $(1-4 \mu \mathrm{g} / \mathrm{mL})$ for the standard curve. The total carotenoid content was expressed based on $\beta$ carotene equivalents ( $\beta$-carotene; $\mathrm{mg} / \mathrm{g}$ dry weight). Determination of total betalains. The content of betaxanthins and betacyanins from the obtained extracts was determined using the Shimadzu UV1800 type Spectrophotometer, at $538 \mathrm{~nm}$ and $480 \mathrm{~nm}$ respectively according to the methods described by Ravichandran et al. and Stintzing et al. [19, 22]. The registered absorbance was used to calculate the betalain concentration for each sample. The betalain content (BC) was calculated as:

$$
B C(m g / m L)=\frac{A \times D F \times M \times 1000}{\varepsilon \times l},
$$

where $\mathrm{A}=$ absorbance, $\mathrm{DF}=$ the dilution factor and 1 the pathlength of the cuvette $(1 \mathrm{~cm}), \mathrm{M}=$ the molecular weights $(550 \mathrm{~g} / \mathrm{mol}$ for betacyanins and $308 \mathrm{~g} / \mathrm{mol}$ for betaxanthins), $\varepsilon=$ molar extinction coefficients $(60000 \mathrm{~L} / \mathrm{mol} \mathrm{x} \mathrm{cm} \mathrm{for} \mathrm{betacyanins} \mathrm{and}$ $48000 \mathrm{~L} / \mathrm{mol} \mathrm{x} \mathrm{cm}$ for betaxanthins).

Determination of total saponins (TSC). It was used vanillin-sulphuric acid assay [12]. Briefly, $0.5 \mathrm{~mL}$ of each samples (reagent blank, extracts, or diosgenin) were incubated at $60^{\circ} \mathrm{C}$ with $0.5 \mathrm{~mL} 8 \%$ (w/v) vanillin in ethanol $(96.9 \%)$ and $5 \mathrm{~mL}$ of $72 \%$ (v/v) sulphuric acid in water. The absorbance of the diosgenin and extracts were measured at $544 \mathrm{~nm}$ against the reagent blank, using a UV-VIS spectrophotometer (Jasco V-530, Tokyo, Japan), after cooling for $5 \mathrm{~min}$ at room temperature. The TSC was expressed in mg of standard equivalents per $\mathrm{mL}$ of extract (mg diosgenin/mL).

HPLC analysis. All standards (Table II) were purchased from Sigma-Aldrich (Germany). Stock solutions of all the standards were prepared in methanol. Phenolic compounds were evaluated by reversed phase - high performance liquid chromatography (RP-HPLC) with direct injection. Chromatographic analysis was carried out with a Thermo Finnigan Surveyor Plus equipped with a Surveyor Photodiode Array Detector (PDA), Surveyor autosampler, Surveyor LC Pump (Quaternary gradient) and Chrome Quest Chromatography Work-station. The separation was performed using an Accuacore PFP $(2.6 \mu \mathrm{m}, 100 \mathrm{~mm}$ $\times 2.1 \mathrm{~mm}$ ) column at $30^{\circ} \mathrm{C}$. The flow rate was 0.4 $\mathrm{mL} / \mathrm{min}$. The mobile phase was composed of 
solvent (A) $0.1 \%$ formic acid in water and solvent (B) $0.1 \%$ formic acid in acetonitrile using a gradient elution applied as follows: 0 - 30 min from 98 $70 \%$ A, 30 - 35 min from $70-25 \%$ A, 35 - 40 min from $25-98 \% \mathrm{~A}, 40-50 \mathrm{~min}$, washing and reequilibration of the column. The injection volume was $1 \mu \mathrm{L}$, while $280 \mathrm{~nm}$ was the detection wavelength [13].

TEAC assay (Trolox Equivalent Antioxidant Capacity). The method is based on the ability of antioxidants to quench the long-lived $\mathrm{ABTS}^{{ }^{+}}$, a bluegreen chromophore with characteristic absorption at $734 \mathrm{~nm}$ according to Pellegrini et al. [16]. Results were expressed relative to Trolox, in mmol of Trolox per $\mathrm{mL}$ extract.

$D P P H$ assay. Sample stock solutions were diluted to final concentrations of $30-0.3 \mathrm{mg} / \mathrm{mL}$ in $70 \%$ ethanol. The positive controls were represented by a standard solution (gallic acid). The $\mathrm{EC}_{50}$ values were calculated by linear regression of plots where the abscissa represented the concentration of tested plant extracts and the ordinate the average percent of antioxidant activity [7].

Evaluation of the antimicrobial activity of the studied phytochemical mixtures. For testing the antimicrobial activity there were used reference and clinically isolated microbial strains, belonging to Gram-positive (Bacillus subtilis, Staphylococcus aureus, Enterococcus fecalis) Gram-negative (Pseudomonas aeruginosa, Escherichia coli, Klebsiella pneumoniae, Acinetobacter baumannii) bacteria and yeasts (Candida famata, C. utilis, C. albicans).

Qualitative screening of the antimicrobial activity. For assessing the antimicrobial activity, microbial suspensions were prepared from 18 - $24 \mathrm{~h}$ cultures grown on solid medium and adjusted to 0.5 McFarland standard. The qualitative antimicrobial activity was determined by disc diffusion method. The stock solutions were the alcoholic plant extracts, as well as the chemical compounds identified by HPLC in the studied extracts and also solvent control,

represented by $70 \%$ ethanol. The microbial growth inhibition area at around the solution spot was interpreted as a positive result [25].

Quantitative assessment of the minimal inhibitory concentration (MIC). Quantitative analysis was performed by binary serial microdilution method in liquid medium (broth for bacteria and Sabouraud for yeasts) in 96-well plates using the solvent control (70\% ethanol). The concentration range of the working stock solutions for alcoholic extracts was from 0.78 to $400 \mu \mathrm{L} / \mathrm{mL}$. At the same time, serial dilutions were made with $70 \%$ ethanol in the same working conditions in order to obtain the negative control. Each well was inoculated with $10 \mu \mathrm{L}$ microbial suspension adjusted to $0.5 \mathrm{McF}$ arland standard from $20-24 \mathrm{~h}$ cultures grown. MIC was established both macroscopically, as the last concentration at which no microbial growth was observed, and spectrophotometrically by measuring microbial cultures' absorbance was measured at $620 \mathrm{~nm}$ using the spectrophotometer Apollo LB 911 [13].

Influence of P. americana extracts on inert surface adherence capacity. The influence on the ability of adherence to the inert substrate were measured after the quantitative analysis protocol of the antimicrobial effect, through the microtiter method, evaluating the biomass, after fixation with cold methanol and crystal violet staining ( $1 \%$ concentration for dye). The absorbance of the biological material resuspended with acetic acid (33\%) was determined by reading the absorbance at $490 \mathrm{~nm}$.

\section{Results and Discussion}

Chemical Composition and Antioxidant Activity Table I shows the total phenols, flavonoids, betalains, saponins, carotenoids and the antioxidant activity of $P$. americana fruits and leaves extracts. The leaves extract exhibited a higher phenols content compared with fruits [26].

Table I

Total phenols, flavonoids, betalains, saponins, carotenoids and antioxidant activity of $P$. americana samples

\begin{tabular}{lcc}
\hline \multicolumn{1}{c}{ Parameters } & P. americana leaves extract & $P$. americana berries extract \\
\hline Total phenols content $(\mu \mathrm{g}$ GAE$/ \mathrm{mL}$ extract $)$ & 323.80 & 144.70 \\
\hline Total flavonoids content $(\mu \mathrm{g} \mathrm{QE} / \mathrm{mL}$ extract $)$ & 9.27 & 3.47 \\
\hline$\%$ flavonoids content from total phenolic content & 2.86 & 2.40 \\
\hline Total betalains content $(\mu \mathrm{g} / \mathrm{L}$ extract $)$ & 45.62 & 113.77 \\
\hline$\%$ betacyannins from total betalains content & 39.78 & 76.11 \\
\hline$\%$ betaxanthins from total betalains content & 60.22 & 23.89 \\
\hline Total carotenoids content $(\mu \mathrm{g} \beta$-carotene equivalent $/ \mathrm{mL}$ extract $)$ & 3.48 & 1.07 \\
\hline Total saponins content $(\mathrm{mg}$ diosgenin/mL) & 1.61 & 0.59 \\
\hline TEAC assay $(\mathrm{mmol}$ Trolox $/ \mathrm{mL}$ extract $)$ & 2.71 & 1.06 \\
\hline DPPH assay $\mathrm{IC}_{50}(\mathrm{mg} / \mathrm{mL})$ & 2.29 & 18.17 \\
\hline
\end{tabular}

The leaves extract has a higher amount of flavonoids and representing approximately $2.94 \%$ of total phenols, results confirmed by the literature [9].
As expected, betacyanins content was higher in the fruits extract, while the leaves extract had a higher content in betaxanthin. The antioxidant activity 
(either TEAC or DPPH assay) was superior for the leaves extract and it is correlated with the total content of phenols, flavonoids and carotenoids, in agreement with the literature [26].

Most of the compounds identified through HPLC were from the leaves extract (Table II, Figure 1) accounting about $30.88 \%$ of the total phenol content quantified by the Folin Ciocâlteu method, the major components being chlorogenic acid, 4-hydroxybenzoic acid, followed by rutin and ellagic acid. According to Proestos et al. [18], P. americana leaves contain caffeic, p-coumaric, vanillic, 4-hidroxibenzoic acids, and rutin. So far, the phenolic profile of Phytolacca fruits was a relatively poorly addressed topic.

Table II

HPLC analysis of phenols from extracts of $P$. americana leaves and fruits

\begin{tabular}{|c|c|c|}
\hline \multirow{2}{*}{ Analytical standards } & P. americana leaves extract & P. americana berries extract \\
\hline & \multicolumn{2}{|c|}{$\mu$ g compound $/ \mathrm{mL}$ extract } \\
\hline Gallic acid & n.d. & 0.33 \\
\hline 3,4-dihydroxybenzoic acid & n.d. & 0.13 \\
\hline 4-hydroxybenzoic acid & 12.63 & 1.09 \\
\hline$(+)-$ Catechin & n.d. & 0.83 \\
\hline Caffeic acid & 0.32 & n.d. \\
\hline Chlorogenic acid & 45.95 & 0.10 \\
\hline Syringic acid & 0.16 & n.d. \\
\hline$(-)$ - Epicatechin & 0.30 & 0.39 \\
\hline$p$-Coumaric acid & 1.54 & n.d. \\
\hline Ferulic acid & 0.98 & 0.12 \\
\hline Ellagic acid & 4.04 & 0.15 \\
\hline Rutin & 6.94 & 0.22 \\
\hline Resveratrol & 0.11 & 0.69 \\
\hline Quercetin & 0.31 & 0.21 \\
\hline
\end{tabular}

n.d.- not detected

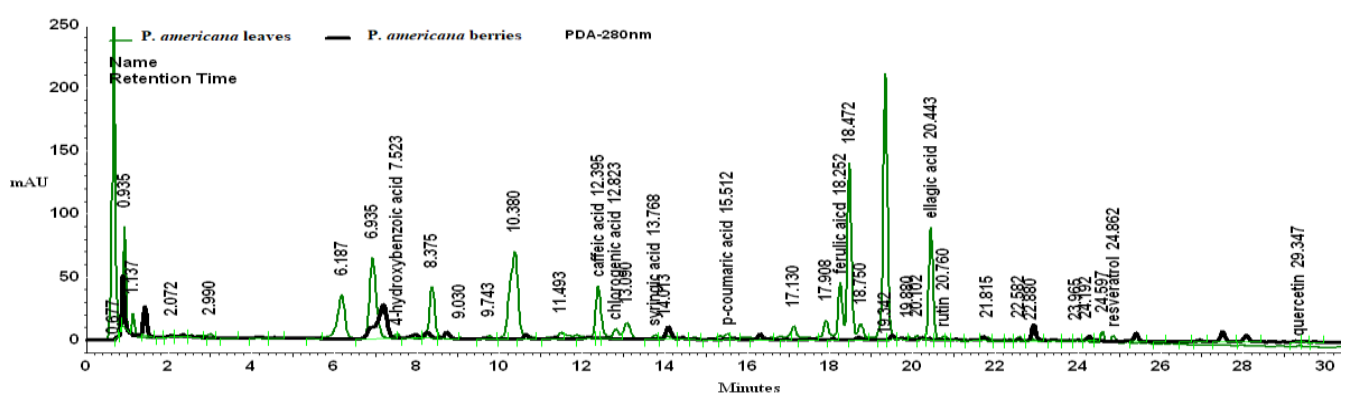

Figure 1.

HPLC chromatograms of $P$. americana leaves (green) and fruits (black) extracts

\section{Antimicrobial Activity}

We have included in the study those microbial strains which proved to be sensitive to the extracts studied by the qualitative assay. The MIC assay revealed a broad spectrum of antimicrobial activity against the studied microorganisms. The comparative results of the antimicrobial activity obtained for the vegetative and reproductive organs extracts and the differences between them and the solvent are shown in Table III.

Figure 2 shows the antibacterial (against $K$. pneumoniae and $E$. coli) and antifungal activity (against $C$. famata) of $P$. americana leaves and fruits extracts as well as of the used solvent (ethanol).

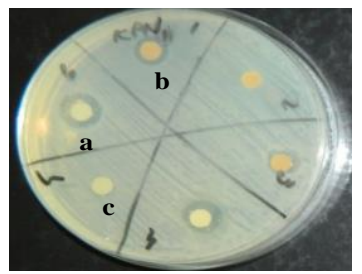

K. pneumoniae

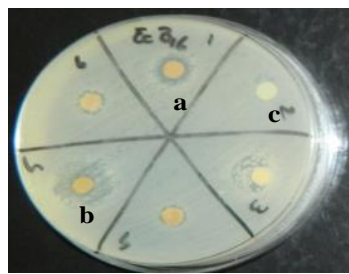

E. coli

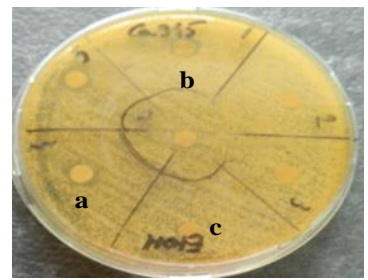

C. famata

Figure 2.

The occurrence of the antibacterial and antifungal activities of the tested $P$. americana leaves and fruits extracts. $\mathrm{a}$ - leaves extracts; $\mathrm{b}$ - fruits extracts; c - solvent (ethanol 70\%) 
The antimicrobial and anti-biofilm activities of $P$. americana leaves and fruits alcoholic extracts $v s$. solvent control

\begin{tabular}{|c|c|c|c|c|c|c|c|c|c|}
\hline \multirow[b]{2}{*}{ Microbial strains } & \multicolumn{3}{|c|}{$P$. americana leaves } & \multicolumn{3}{|c|}{ P. americana fruits } & \multicolumn{3}{|c|}{ Solvent control (70\% ethanol) } \\
\hline & 1 & 2 & 3 & 1 & 2 & 3 & 1 & 2 & 3 \\
\hline S. aureus ATCC 6538 & - & - & - & ++ & 50 & 6.25 & - & 200 & 100 \\
\hline S. aureus MRSA 1263 & - & - & - & ++ & 100 & 25 & - & 400 & 200 \\
\hline B. subtilis 6683 & + & 100 & 100 & + & 50 & 6.25 & - & 200 & 100 \\
\hline B. subtilis 12488 & ++ & 25 & 25 & ++ & 200 & 100 & - & 400 & 200 \\
\hline E. coli ATCC 8739 & + & 100 & 100 & + & 100 & 100 & - & 200 & 200 \\
\hline E. coli $\mathrm{O}_{126} \mathrm{~B}_{16}$ & + & $>200$ & 200 & \pm & 100 & 50 & - & 400 & 200 \\
\hline K. pneumoniae 134202 & + & $>200$ & $>200$ & + & 50 & 25 & + & 200 & 100 \\
\hline K. pneumoniae 11 & ++ & 200 & 25 & + & $>200$ & 100 & + & 200 & 100 \\
\hline P. aeruginosa ATCC 27853 & + & 50 & 50 & ++ & 100 & 50 & - & 200 & 200 \\
\hline$P$. aeruginosa $326 \mathrm{sc}$ & + & $>200$ & 100 & - & - & - & - & 400 & 400 \\
\hline A. baumannii $77 \mathrm{sc}$ & + & 100 & 50 & + & 100 & 12.5 & + & 200 & 100 \\
\hline C. utillis & + & 50 & 50 & + & 50 & 50 & + & 200 & 200 \\
\hline C. famata & + & 100 & 25 & + & 50 & 6.25 & - & 200 & 100 \\
\hline C. albicans 945 & + & $>200$ & 200 & + & 100 & 50 & + & 200 & 100 \\
\hline C. albicans 393 & ++ & 200 & 50 & ++ & 50 & 6.25 & + & 200 & 100 \\
\hline C. albicans ATCC & - & - & - & + & 50 & 12.5 & - & 400 & 200 \\
\hline
\end{tabular}

1 - qualitative antimicrobial activity; 2 - MIC; 3 - minimum inhibitory concentration of the microbial ability to adhere to the inert substrate eradication; -: $5 \mathrm{~mm}$; \pm : 6 - $8 \mathrm{~mm}$; +: 9 - 13mm; ++: 14 - $20 \mathrm{~mm}$.

The minimum inhibitory concentrations of alcoholic extracts of $P$. americana range from 25 to $200 \mu \mathrm{L} / \mathrm{mL}$, the fruits extract being more active. The Gram-positive strains proved to be most sensitive to the studied phytochemical mixtures, leading to the conclusion that the outer membrane of Gramnegative bacteria functions as an additional barrier which limits the penetration of the active principles [14] and phenolic acids proved to be more active on the studied microbial strains in comparison with the flavonoids.

The antimicrobial activity of saponins is somewhat controversial. The saponins are detergent-like substances that have antibacterial as well as antifungal potential. However, there are studies that have shown that the saponin from Quillaja saponaria bark e.g. (20 - 35\% sapogenin which has quillaic acid, a triterpene of the $\mathrm{D}^{12}$-oleanane type, as main aglycone) stimulates the growth of $E$. coli strains due to increased flow of environmental nutrients in cells, at a dose of $12 \mu \mathrm{g} / \mathrm{mL}$ [1]. On the other side, Butassi et al. [4] have shown that the dichloromethane extract from berries (PtDEb) showed the best antifungal activity from twelve Phytolacca tetramera extracts tested against $C$. albicans and $C$. glabrata. The main active markers were phytolaccagenin and phytolaccoside $\mathrm{B}$, that were also identified in $P$. americana.

The phytochemical mixtures decreased the ability of the tested strains to colonize the inert substratum adherence leading to the inhibition of microbial biofilm development.

The adherence to inert substrate was inhibited for all microbial strains tested at concentrations ranging from 6.25 to $200 \mu \mathrm{L} / \mathrm{mL}$, the extract obtained from $P$. americana fruit proving to be the most active on Gram positive strains adherence probably due to the betalains and phenolic acids high content (Table III). The influence of $P$. americana extracts on the microbial adherence capacity is reported for the first time in this study and extends the potential applications of this medicinal herb for the design of novel antimicrobial strategies for topical treatments. In accordance with Borges et al. [3], natural phenols present antiadhesion capacity, thus inhibiting the first step of microbial biofilm formation. Among the tested analytical standards, phenolic acids proved to be the most active. The microbial membrane destabilization and especially the antimicrobial activity of phenolic compounds at relatively low concentrations is most likely caused by a $\mathrm{pH}$ decrease, due to hydroxyl groups, thus supporting a possible role for the mutual cation exchange at the level of the cell membrane leading to its destabilization [23]. In addition, the phenolic nucleus could interfere with cellular wall proteins involved in the microbial adhesion [15].

\section{Conclusions}

The phytochemical mixture of $P$. americana leaves and fruits proved to be rich in phenols and carotenoids, compounds known for their strong antioxidant capacity. The HPLC analysis performed in our study completes the lack of information about the profile of Phytolacca phenolic compounds. The $P$. americana fruits extract proved to be more active compared with the leaves one, in terms of antimicrobial activity, probably due to the content 
of betalains, catechins and gallic acid, compounds which are missing in the case of leaves extract. The tested $P$. americana extracts inhibited the adherence of microbial cells and their ability to form biofilms on the inert substratum, these properties being for the first time reported in our paper. Our results reflect the potential of alcoholic extracts to be used as therapeutic agents complementary to antibiotherapy.

\section{Acknowledgement}

This research was funded by O.I.M., research project ICUB 29604/12.12.2019 and FDI-CREATOR 20200355 .

\section{Conflict of interest}

The authors declare no conflict of interest.

\section{References}

1. Arabski M, Węgierek-Ciuk A, Czerwonka G, Lankoff A, Kaca W, Effects of Saponins against Clinical E. coli Strains and Eukaryotic Cell Line. $J$ Biomed Biotechnol., 2012; 2012: 1-6.

2. Bailly C, Vergoten G, Esculentosides: Insights into the potential health benefits, mechanisms of action and molecular targets. Phytomedicine, 2020; 79: 153343, doi: 10.1016/j.phymed.2020.153343.

3. Borges A, Simões LC, Saavedra MJ, Simões M, The action of selected isothiocyanates on bacterial biofilm prevention and control. Int Biodeterior Biodegradation, 2014; 86: 25-33.

4. Butassi E, Svetaz LA, Zhou S, Wolfender JL, Cortés JCG, Ribas JC, Díaz C, Palacio JP del, Vicente F, Zacchino SA, The antifungal activity and mechanisms of action of quantified extracts from berries, leaves and roots of Phytolacca tetramera. Phytomedicine, 2019; 60: 152884: 1-9,

5. Choe S, Jeong S, Jang M, Yeom H, Moon S, Kang M, Yang W, Kim S, Identification of phytolaccosides in biological samples from pokeweed intoxication patients using liquid chromatographytandem mass spectrometry. J Chromatogr B, 2020; 1149: 122123: 1-9.

6. Ciulei I, Istudor V, Palade M, Niculete E, Gîrd C, Pharmacognostic and phytochemical analysis of plant products. Tehnoplast Company S.R.L. Publishing House, Bcharest, 1995, (available in Romanian).

7. Costea T, Hudiţă A, Olaru OT, Gălăţeanu B, Gîrd CE, Mocanu MM, Chemical composition, antioxidant activity and cytotoxic effects of Romanian Craterellus cornucopioides (L.) pers. mushroom. Farmacia, 2020; 68(2): 340-347.

8. Daglia M, Polyphenols as antimicrobial agents. Curr Opin Biotechnol., 2012; 23(2): 174-181.

9. Ebrahimzadeh MA, Nabavi SF, Nabavi SM, Pourmorad F, Nitric oxide radical scavenging potential of some Elburz medicinal plants. African $J$ Biotechnol., 2010; 9(32): 5212-5217.

10. Ishag HZA, Li C, Huang L, Sun M, Ni B, Guo C, Mao X, Inhibition of Japanese encephalitis virus infection in vitro and in vivo by pokeweed antiviral protein. Virus Res., 2013; 171(1): 89-96.

11. Krochmal A, LeQuesne P, Pokeweed (Phytolacca americana): Possible source of a molluscicide. Res. Pap. NE-177. Upper Darby, PA: U.S. Department of Agriculture, Forest Service, Northeastern Forest Experiment Station, 1970; 1-8.

12. Le AV, Parks SE, Nguyen MH, Roach PD, Improving the Vanillin-Sulphuric Acid Method for Quantifying Total Saponins. Technologies, 2018; 6(3): 84: 1-12.

13. Marinas I, Oprea E, Geana E-I, Chifiriuc CM, Lazar $\mathrm{V}$, Antimicrobial and antioxidant activity of the vegetative and reproductive organs of Robinia pseudoacacia. J Serbian Chem Soc., 2014; 79(11): 1363-1378.

14. Mihăescu G, Chifiriuc M, Ditu L, Antibiotics and antimicrobial chemotherapeutic substances; Romanian Academy Publishing House, Bucharest, 2007, (available in Romanian).

15. Ozdal T, Capanoglu E, Altay F, A review on proteinphenolic interactions and associated changes. Food Res Int., 2013; 51(2): 954-970.

16. Pellegrini N, Serafini M, Colombi B, Del Rio D, Salvatore S, Bianchi M, Brighenti F, Total Antioxidant Capacity of Plant Foods, Beverages and Oils Consumed in Italy Assessed by Three Different In Vitro Assays. J Nutr., 2003; 133(9): 2812-2819.

17. Pîrvu L, Sha'at F, Păvăloiu R, Udeanu DI, Albu B, Studies on Acinos alpinus L.: polyphenols and terpenoids compounds profile, antimicrobial activity, antioxidant effect and release experiments on the ethanol and propylene glycol extracts. Farmacia, 2019; 67(6): 1025-1033.

18. Proestos C, Boziaris IS, Nychas G-JE, Komaitis M, Analysis of flavonoids and phenolic acids in Greek aromatic plants: Investigation of their antioxidant capacity and antimicrobial activity. Food Chem., 2006; 95(4): 664-671.

19. Ravichandran K, Saw NMMT, Mohdaly AAA, Gabr AMM, Kastell A, Riedel H, Cai Z, Knorr D, Smetanska I, Impact of processing of red beet on betalain content and antioxidant activity. Food Res Int., 2013; 50(2): 670-675.

20. Ravikiran G, Raju A, Venugopal Y, Phytolacca americana: A Review. Int J Res Pharma Biomed Sci., 2011; 2(3): 942-946.

21. Singleton V, Rossi J, Colorimetry of Total Phenolics with Phosphomolybdic-Phosphotungstic Acid Reagents. J Enol Vitic., 1965; 16(3): 144-158.

22. Stintzing FC, Schieber A, Carle R, Evaluation of colour properties and chemical quality parameters of cactus juices. Eur Food Res Technol., 2003; 216(4): 303-311.

23. Ultee A, Bennik MHJ, Moezelaar R, The Phenolic Hydroxyl Group of Carvacrol Is Essential for Action against the Food-Borne Pathogen Bacillus cereus. Appl Environ Microbiol., 2002; 68(4): 1561-1568.

24. Woisky RG, Salatino A, Analysis of propolis: some parameters and procedures for chemical quality control. J Apic Res., 1998; 37(2): 99-105.

25. Zarafu I, Pătrașcu B, Măruțescu L, Bleotu C, Limban C, Tatibouët A, Chifiriuc MC, Nuță DC, 
FARMACIA, 2021, Vol. 69, 5

Ioniță P, Bioevaluation of the antimicrobial and antiproliferative potential of some derivatives of 3,5-dinitro-4-

26. Zheleva-Dimitrova D, Antioxidant and acetylcholinesterase methoxyamino-benzoic acid. Farmacia, 2020; 68(1): 8-14. inhibition properties of Amorpha fruticosa $\mathrm{L}$. and Phytolacca americana L. Pharmacogn Mag., 2013; 9(34): 109-113. 